\title{
IMPROVING THE FINANCIAL KNOWLEDGE OF THE OLDER GENERATION - THE PLEKHANOV UNIVERSITY EXPERIENCE
}

Olga A. Grishina, Dinara R. Tutaeva, Alexey I. Grishin, Plekhanov Russian University of Economics, Russia

\section{Older people in the modern labour market}

It is not a secret that the level of social development of some certain society is not least of all characterized by the attitude towards the senior and older people. The problems and challenges faced by these groups of citizens have never been easy to solve, and in the modern world, they became even more complicated. Among the challenges that have become particularly relevant in recent years, the first that is worth mentioning is the accelerated development of technologies, above all - informational ones. Often, senior and older people are not able to adapt quickly to these changes, and at best, they experience problems in their daily life. In the worst case, this situation leads to the fact that these categories of citizens become "lagging behind", which is especially painful for people who are specialists in their fields. Despite their knowledge and often invaluable experience, their working competencies are rapidly becoming obsolete. This not only significantly hinders the effective work of such people, but also puts them in a vulnerable position in the labour market, and often becomes the cause of personal psychological problems.

This problem is very serious for countries with the constructive (regressive by Sundberg's classification) model of the population pyramid, which is characterized by the so-called "mound of the elders". One of the characteristic features of this demographic situation is the massive presence in the labour market of people of pre-retirement age, as well as a significant percentage of pensioners who continue to work. Russia is among the countries experiencing this situation to the full extent. The dynamics of the number of working citizens of Russia of pre-retirement age and retirement age in recent years According to data of the Russian Federal State Statistics Service (FSSS) is shown in the table 1:

Table 2: The number of working citizens of Russia of pre-retirement age and retirement age

\begin{tabular}{ccc}
\hline Year & $\begin{array}{c}\text { Citizens of pre-retirement age } \\
\text { (men of 55-59 y.o.; women of 50-54 y.o.), } \\
\text { thous. }\end{array}$ & $\begin{array}{c}\text { Citizens of retirement age } \\
\text { (men of 60-72 y.o. / women of 55-65 y.o.), } \\
\text { thous. }\end{array}$ \\
\hline 2009 & 8,316 & 5,802 \\
2011 & 8,571 & 6,288 \\
2013 & 8,666 & 6,563 \\
2015 & 8,907 & 7,106 \\
2017 & 8,690 & 7,315 \\
\hline
\end{tabular}


Thus, with relative stability (in absolute digits) in the number of working citizens of preretirement age, there is a steady increase in the number of working retirees. Thus, in accordance with FSSS data for 2017, out of a total number of Russian retirees of 42.7 million people, about 13.1 million continued to work, forming the proportion of about $30.7 \%$. It is also worth mentioning that out of this total number of retirees, about 35.3 million people $(82.7 \%)$ receive an old-age insurance pension; 7.4 million people $(17.3 \%)$ receive a social retirement pension.

Of course, older workers have a number of guarantees, including legislation ones. Thus, in accordance with the Labour Code of the Russian Federation, age is not a reason for dismissing an employee, and unreasonable dismissal of an employee of pre-retirement age at the initiative of the employer entails criminal liability in accordance with article 144.1 of the Criminal Code of the Russian Federation (which is in force since 2019). According to the same article, the employer is also responsible for the unreasonable refusal to hire persons who will have a retirement age in the next five years or less (under labour law, responsibility arises on the basis of article 64 of the Labour Code of the Russian Federation). None of the above, however, is able to protect older workers from the problems identified at the beginning of the article.

\section{What makes older people work}

So, what makes older people work? Various surveys conducted in Russia over the past four years allow us to highlight the following key drivers:

- $\quad$ low pension (the desire to receive additional income);

- need for communication;

- habit of work;

- striving for financial independence.

Somewhat different results were obtained from the study conducted in 2018 by the Silver Generation University of the Plekhanov Russian University of Economics. Founded in 2014 by Plekhanov RUE Faculty of Distance Learning, the Silver Generation University studies the needs of the older generation, organizes and conducts educational activities aimed at improving the performance of active retirees, as well as enhancing the interaction of the younger and older generations. The events of the Silver Generation are aimed at supporting the personal and social status of the elderly person, prolonging maximally the active lifestyle of the older generation, as well as organizing leisure activities taking into account the interests of the elderly and thus contributing to the formation of a stable emotional state for them. The results of the aforementioned study revealed the following reasons that drive pensioners to continue working:

- fear of poverty;

- love to work;

- the desire to help children / grandchildren. 
It can be said for certain that the main reason why older people continue to work is of a financial nature. In this light, the key task facing the society as a whole and the employer in particular is to help older workers overcome the fear of a subsequent life for an insufficient pension, that is, the fear of poverty. The results of the Silver Generation University activity allowed to formulate three main directions for solving this problem:

- ensure the employer's interest in preserving jobs for older workers;

- providing psychological support;

- enhance personal applied financial literacy.

In the case of the first direction, the main objects of work of the University were enterprisesemployers. Their interest in keeping older employees in the workplace was decided to increase, relying on the role of employees' confidence in the future in increasing loyalty to the employer. The latter, in turn, ensures steady growth in the productivity and efficiency of workers. The provision of psychological support has been delegated to invited experts in this field. The direction connected with the increase of personal applied financial literacy, as carrying educational nature, was considered a priority for the Silver Generation University and required the development of special educational programs.

\section{How to teach older people on a working place?}

In developing the content of the relevant educational programs, it was decided to rely on the following topics:

- personal finance planning, cost optimization, and passive income management;

- acquaintance with various kinds of frauds in the financial environment (including using modern information technologies) in order to reduce the risk of becoming a victim.

The most significant problem was the choice of educational practices, which would meet best the needs of the audience (working men aged 55-70 years and working women aged 50-65 years). According to target audience surveys, a number of educational practices have been selected and implemented within the bounds of the pilot project. The latter was conducted by the Silver Generation University from September to December 2018 at the Sberbank of Russia Centre of Client Operations Support (CCOS), which employs about 3,500 people at the same time, of which about 1,000 are pre-pension and retirement age. In total, 482 employees took part in the project.

Within the pilot project, the following educational practices were used:

- On-line trainings. Within the framework of this format, educational and training materials were sent to audiences via e-mail. Special attention was paid to the structure of the information in the distributed materials, which was supposed to be quite intelligible, but at the same time maintaining academic integrity. In particular, a number of case-studies and step-by-step algorithmic instructions were included. 
- Webinars organized before or after the workday. At the same time, given that the webinars have practically 'lengthened' the working day, the organizers limited the length of these webinars to 30 minutes.

- "Live" (face-to-face) short-term sessions. These were also organized before or after the work day, as well as during the lunch break, and included mostly practical exercises and Q\&A sessions.

- Demonstration of short fascinating videos on financial literacy on TV screens installed in the CCOS canteens. This format turned out to be unexpectedly popular afterwards, many listeners noted that they had discussed with interest what they had just seen with their colleagues right here, when having a meal.

In the course of the project, a very specific problem was noted - a significant proportion of listeners faced a notable "last mile" effect. After obtaining the necessary knowledge, the direct implementation of certain actions (for example, registration in the on-line banking system) still caused difficulties. Also, the high value of teamwork for older listeners was noted - the implementation of certain tasks was greatly facilitated if they were performed together with colleagues. Therefore, it was decided to include the implementation of such tasks in the "live" sessions mentioned above, and invite specialists - managers of banks, insurance companies, tax consultants, etc. - who would act as instructors during these sessions.

After the completion of the pilot project, a survey was conducted with the purpose of feedback receiving. The survey consisted of a set of questions of a digital evaluative type, as well as a series of open questions. In the set of 20 questions of a digital evaluative type, a modified Likert scale was used (from 1 to 5); the average score was 4.61. According to the analysis of answers to open questions, it was found that the audience as a whole was satisfied with the organization of the learning process. Wishes were expressed to increase the number of short-term 'live' sessions, as well as to include in the program some basic information about the organization of small business and various forms of earnings on the Internet. The Sberbank of Russia CCOS management was satisfied with the program, which was recommended by them to be implemented by other Russian banks - members of the Association of Russian Banks (ARB).

Thus, the experience of the Plekhanov RUE Silver Generation University shows that the highest effectiveness in solving the problem of increasing the financial literacy of older people may be achieved only by combining of educational techniques selected specially in regards to this particular audience's features. The development of educational programs in this field continues and will undoubtedly lead to a further increase in the effectiveness of measures to improve the quality of life of older citizens. 


\section{References}

Dirksen, J. (2015). Design for How People Learn (Voices that Matter) (2 ${ }^{\text {nd }}$ ed.). Berkeley, CA: New Riders. 1249 Eighth Street.

NewtoNew (2018). How do those who are over 50 study in Russia? (Как учатся в России те, кому за 50 in Russian). Retrieved 11 March, 2019, from

https://newtonew.com/culture/kak-uchatsya-v-rossii-te-komu-za-50/

Russian Federal State Statistics Service official web-site. Population data (2009-2017).

Retrieved 11 March, 2019, from

http://www.gks.ru/wps/wcm/connect/rosstat_main/rosstat/en/figures/population/ 